\title{
Phylogenetic analysis of transparent gobies in three Sumatran lakes, inferred from mitochondrial Cytochrome Oxidase I (COI) gene
}

\author{
DEWI IMELDA ROESMA`, DJONG HON TJONG, DYTA RABBANI AIDIL \\ Department of Biology, Faculty of Mathematics and Natural Sciences, Universitas Andalas. Jl. Univ Andalas, Kampus Limau Manis, Padang 25163 , \\ West Sumatra, Indonesia. Tel./fax.: +62-751-71671, `email: dewiroesma @ sci.unand.ac.id
}

Manuscript received: 7 November 2019. Revision accepted: 2 December 2019.

\begin{abstract}
Roesma DI, Tjong DH, Aidil DR. 2020. Phylogenetic analysis of transparent gobies in three Sumatran lakes, inferred from mitochondrial Cytochrome Oxidase I (COI) gene. Biodiversitas 21: 43-48. The transparent gobies fish found in three lakes in Sumatra island is known as Rinuak fish (in Maninjau Lake and Singkarak Lake, West Sumatra, Indonesia) or Badar fish (in Siais Lake, North Sumatra, Indonesia), and are morphologically very similar to the Gobiopterus brachypterus. The phylogenetic study was carried out by analyzing 619 base pairs of the mitochondrial DNA cytochrome oxidase subunit I (COI) gene in 12 fish individuals from the three lakes. Rinuak and Badar fish in three populations have four haplotypes. The sequence divergences in and between populations are very low $(0.0-0.5 \%)$. This value indicates that Rinuak and Badar fish are the same species with low genetic diversity. The phylogenetic tree illustrates that this fish belongs to the group of Gobiidae and a sister taxon from G. brachypterus.
\end{abstract}

Keywords: Badar Fish, COI, Genetic diversity, Gobiopterus brachypterus, Rinuak Fish

\section{INTRODUCTION}

Freshwater fishes biodiversity in Indonesia forms one of the largest in the world but poorly documented. There are at least 1189 native species, whereas 125 of them are endemic to the country (Froese and Pauly 2014). Sumatra island a high level of biodiversity of freshwater fishes with a high degree of endemism (Sodhi and Brook 2006; Pfeil 2009), including a small transparent fish that morphologically shows the character of the Gobiidae group. The fish locally is known as Rinuak fish, with the total length range 19.91 to $22.68 \mathrm{~mm}$ and previously considered as an endemic species of Maninjau Lake. The fish have an economically important value as food. Roesma and Santoso (2010) reported a species suspected to be the same as Rinuak fish, that locally named as Badar fish found in Siais Lake, North Sumatra, Indonesia. However, the scientific name of these two species remained unknown, and some local people consider it as a juvenile form of Rasbora from Maninjau Lake, West Sumatra, Indonesia.

Rinuak and Badar fish can be classified as the Gobiidae group because they have the main characters of Gobies, i.e. a pair of pectoral fins that are fused to form suckers and blunt head with big eyes (Kottelat et al. 1993). In addition, the Rinuak and Badar fish are similar to Gobiopterus brachypterus (transparent gobies). Gobiopterus is a genus of gobies with small size, native to freshwater, marine or brackish waters, and one genus of transparent gobies (Kottelat et al. 1993). Biological and ecological information on Rinuak and Badar fish are very scanty, limited only on the study of processed quality of Rinuak as food (Astuti et al. 2016). A previous study (Periwaldi
2012) reported that Rinuak fish in Maninjau Lake and Badar fish in Siais Lake have high morphological differentiations, i.e. 13 different characters of 20 characters.

In the past, the classification of the gobies group was generally based on the external characters (Pezold 1993; Akihito et al. 2000; Nelson 2006); however, identification of the species level was proven to be difficult and problematic. Recently, the advances in molecular approaches have provided the complement to the limited of morphological data for untangling gobioid group (Aquino et al. 2011; Jeon et al. 2012; Agorreta and Ruber 2012; Agoretta et al. 2013; Tornabene et al. 2013; Taillebois et al. 2014; Thacker 2009; Thacker 2015; Wang et al. 2017). Mitochondrial DNA (mtDNA) markers have been widely used for most systematic molecular studies because they have a large number of copies, maternally inherited, and have a higher mutation rate compared to nuclear DNA (Brown et al. 1979; Johns and Avise 1998). Mitochondrial cytochrome oxidase subunit I (COI) gene could serve as a rapid and reliable barcoding marker for identifying species and effective in delimitating species of various animals (Hebert et al. 2004; Hubert et al. 2008; Imtiaz et al. 2017; Roesma et al. 2018; Roesma et al. 2019). Recently, the COI gene has been widely used to resolve the taxonomy in a gobioid group (Jeon et al. 2012; Jin et al. 2014; Taillebois et al. 2014; Wang et al. 2017; Olii et al. 2019). Further research is needed on Rinuak and Badar fish using a molecular approach. The present study aimed to investigate the phylogenetic relationship of Rinuak and Badar fish in three Sumatran Lakes using cytochrome oxidase subunit I (COI) gene. 


\section{MATERIALS AND METHODS}

\section{Study sites}

Rinuak and Badar fish specimens were collected from three Sumatran lakes, i.e. Maninjau Lake and Singkarak Lake in West Sumatra, Indonesia and Siais Lake in North Sumatra, Indonesia. The samples collected with cast-nets and set-nets following standard procedures by Cailliet et al. (1986). Twelve individuals out of the samples were used for phylogenetic analysis and preserved in 96\% ethanol (PA). Other individual specimens were all together fixed in $4 \%$ formalin and preserved into $70 \%$ ethanol for long term storage in the laboratory.

\section{Molecular work}

The DNA extraction was performed following the protocol Kit INVITROGEN PureLink ${ }^{\mathrm{TM}}$ Genomic DNA Mini Kit. The COI was amplified using the following primers: forward primer Fish F1 (5' TCAACCAACCA CAAAGACATTGGC AC 3') and reverse primer Fish R1 (5' TAGACTTCTGGGTGGCCAAAGAATCA 3') (Ward et al. 2005). PCR reactions were conducted in $25 \mu \mathrm{l}$ volumes, containing ; $3 \mu \mathrm{l}$ of DNA template, $11 \mu \mathrm{l}$ of PCR Supermix, $0.5 \mu \mathrm{l}$ of each primer $(0.01 \mathrm{mM})$, and $10 \mu \mathrm{l}$ of DDH20. The PCR procedure was conducted using PCR Sensoquest thermal cyclers with the following program: initial denaturation at $95^{\circ} \mathrm{C}$ for $2 \mathrm{~min} ; 35$ cycles of denaturation at $94^{\circ} \mathrm{C}$ for $30 \mathrm{~s}$, annealing at $54^{\circ} \mathrm{C}$ for $30 \mathrm{~s}$ and elongation at $72^{\circ} \mathrm{C}$ for $1 \mathrm{~min}$; followed by a final extension of $72^{\circ} \mathrm{C}$ for $10 \mathrm{~min}$ and then held at $4^{\circ} \mathrm{C}$ for the long term storage. PCR products were run on $2 \%$ agarose gel and visualized using GelDoc. PCR products were purified and the most powerful products selected for sequencing to $1^{\text {st }}$ Base, Pte. Ltd. in Malaysia.

\section{Data analysis}

The nucleotide sequences from the DNA sequencing of Rinuak and Badar fish was edited using the DNA STAR program (Burland 2000). Then, DNA sequences were obtained compare with the data on the Genbank, NCBI (Table 1.) to investigate the similarity of all sequences in http://blast.ncbi.nlm.nih.gov/Blast.cgi. Sequences were aligned using the Clustal $\mathrm{X}$ default settings and edited using the Bioedit program (Thompson 1997; Hall 1999). DNA SP version 5.10 was used to identify haplotypes numbers $(h)$, polymorphism sites (S), haplotype diversity $(H d)$, and nucleotide diversity (Pi) (Rozas 2003). Pairwise genetic distances were calculated to quantify sequence divergences among all sequences using the $p$-distance Kimura two-parameter (K2P) method in the MEGA version 6.0 program (Tamura et al. 2013). Phylogenetic analyses were performed the four methods; Neighbors Joining (NJ), Maximum Evolution (ME), Maximum Likelihood (ML), and Maximum Parsimony (MP) using 1000 bootstrapping in MEGA 6.0 program (Tamura et al. 2013).

\section{RESULTS AND DISCUSSION}

\section{Sequence data}

The mtDNA COI sequences of 32 individuals (12 sequences from the present study and 20 sequences from the GenBank) were determined for a total of $619 \mathrm{bp}$. Among them, 231 bp (37.32\%) were variable sites, and 213 bp $(34.42 \%)$ were parsimony informative sites. No stop codons, insertions, and deletions were found in its translation. The average compositions of A, T, C, and G nucleotide base was $24.4 \%, 30.3 \%, 27.5 \%$, and $17.8 \%$, respectively. The average composition value was almost similar to the previous studies of Gobiidae (Aquino et al. 2011; Aquilino et al. 2011; Jeon et al. 2012). Nucleotide sequences are AT ratio $(54.7 \%)$ higher than the GC ratio, which is characteristic for the genome of mtDNA in vertebrate (Hubert et al. 2008). The GC content of the first codon is the highest, while the variable second codon has the lowest. The transitions are more common than transversion with bias ratio (Ts; Tv) is R: 3.737. A total of 22 haplotypes consisted of four haplotypes to Rinuak and Badar fish in Sumatran Lakes and 18 haplotypes to data of GenBank, NCBI. The average haplotype diversity among 22 haplotypes $(H d)$ was $0.938 \pm 0.001$ (mean \pm standard deviation), and the average nucleotide diversity $(\pi)$ was $0.16256 \pm 0.002$. While among Rinuak and Badar fish in Sumatra has the haplotype diversity $(H d)$ was 0.561 , and nucleotide diversity $(P i)$ was 0.00142 . Genetic distance within and among populations of Rinuak and Badar fish was $0.0-0.5 \%$ (the table of genetic distance not showed). Sequence divergence between outgroup (Rasbora lateristriata and Danio rerio) with Rinuak and Badar fish lineages ranged from $27.6 \%$ to $31.6 \%$. That value supported that they are in a different family.

\section{Phylogenetic relationships}

The phylogenetic tree was constructed using four methods (ML/NJ/ME/MP) analysis generated almost in identical topologies, represented by the ML tree with 1000 bootstrap replicates (Figure 1.). Based on the tree constructed from COI genes, it can be observed that the Gobiidae group divided into four sublineages.

The phylogenetic tree members consist of Rinuak and Badar fish in the first sublineage, Gobiopterus in the second, and fourth sublineage while Sicyopterus, Stipodon, Sicyopus, and Lentipes in the third sublineage. All members of Rinuak and Badar fish from three Sumatran lakes present together in the first sublineage with sequence divergences was $0.0-0.5 \%$. In the second sublineage, consists of three species from Gobiopterus, namely $G$. brachypterus, G. chuno, and G. lacustris. Among the species of Gobiopterus has sequence divergences was 2.0$17.8 \%$. The presence of small sequence divergences $(2.0 \%)$ between the G. chuno from Bangladesh MK572237 and G. brachypterus from India MG495939 and (3.0\%) between $G$. brachypterus from Central Java and $G$. lacustris from the Philippines is require re-identification studies in taxonomy. According to Kartavsetv et al. (2013), that value indicated for differences at the level of subspecies, semi species, or sibling species. 
The phylogenetic tree showed that the Gobiopterus in the second sublineage is occupying the position as a sister taxa of Rinuak and Badar fish with sequence divergences was $24.6-27.9 \%$. Gobiopterus is the only genus of transparent gobies that has the genetic data used as a comparison for Rinuak and Badar fish. Based on Kartavtsev et al. (2011), Kartavtsev et al. (2013), the value of sequence divergences between first and second sublineages showed differentiation at the level of a different genus. The third Sublineage consists of four different genera. The sequence divergences between them were 11.8-15.3\%, and with both first and second sublineages were 20.7-29.3\%. The fourth Sublineage has one member, $G$. semivestitus, which is separated from other Gobiopterus in the second sublineage with sequence divergences was 27.2-29.1\%. The separation of Gobiopterus into two different sublineages showed that Gobiopterus has the non-monophyletic lineages. The value of sequence divergences between Gobiopterus in the second and fourth sublineages showed differentiation at the level of a different genus. Based on Kartavtsev et al. (2011), Kartavtsev et al. (2013) sequence divergences in the same genus was $11-16 \%$.

\section{Discussion}

The present study represents the first molecular data of Rinuak and Badar fish in Sumatra using mitochondrial markers (COI gene). Rinuak and Badar fish in Sumatra present in one sublineage with low haplotype diversity, which is some individual shared the same haplotype. Refers to Kartavtsev et al. (2011); Kartavtsev et al. (2013), our analysis revealed that the Rinuak and Badar fish are the same species, with low genetic diversity $(0.0-0.5 \%)$. While previously, the morphological study by Periwaldi (2012) showed the substantial morphological differences between Rinuak Maninjau Lake and Badar Siais Lake. Geographically, the three lakes are not connected, no gene flow between the population of the lakes, that causes the geographical isolation. Roesma et al. (2018) explained that the freshwater fauna in Maninjau Lake isolated because of no connection with other waters. Water in the Maninjau Lake comes from small rivers, which is filled by water catchment in the surrounding area and only has one outlet. The low genetic divergences of Rinuak and Badar fish between Lakes indicated that geographic distance and geographical isolation do not correlate their sequence divergences.

Using mtDNA, Mcglasan and Hughes (2001) considered that there was no significant relationship between geographical distance and gene flow on Hypseleotris compressa from different drainages with low genetic differentiation on the populations. Keith et al. (2005) also reported that the Sicyopterus lagocephalus from different distant archipelagos has minimal genetic distances and suggests they as the same species. The study by Arisuryanti et al. (2018) showed that Periophthalmus argentilineatus in Bogowonto Lagoon (Middle Java) and population in Pandeglang (West Java) clustered together with low sequence divergences. $H$. compressa, $S$. lagocephalus, and $P$. argentilineatus are the species from other Gobies. Referring to study Mcglasan and Hughes (2001); Keith et al. (2005), the possibilities conditions of present study are: 1) natural selection is able to maintain the balance of allele frequencies, 2) there is a geographic connection in the past at these distant locations, and 3) the ability of the fish to change.

Table 1. Species list taxonomy, location and GenBank accession number of samples

\begin{tabular}{|c|c|c|c|c|}
\hline Family & Genus & Species & Location & Accession numbers \\
\hline Gobiidae & $\begin{array}{l}\text { Sicyopterus } \\
\text { Stiphodon } \\
\text { Sicyopus } \\
\text { Lentipes }\end{array}$ & $\begin{array}{l}\text { Gobiopterus brachypterus } \\
\text { Gobiopterus brachypterus } \\
\text { Gobiopterus brachypterus } \\
\text { Gobiopterus brachypterus } \\
\text { Gobiopterus brachypterus } \\
\text { Gobiopterus brachypterus } \\
\text { Gobiopterus chuno } \\
\text { Gobiopterus lacustris } \\
\text { Gobiopterus lacustris } \\
\text { Gobiopterus semivestitus } \\
\text { Sicyopterus parvei } \\
\text { Sicyopterus lagocephalus } \\
\text { Stiphodon semoni } \\
\text { Stiphodon maculidorsalis } \\
\text { Sicyopus zosterophorum } \\
\text { Sicyopus ribicundus } \\
\text { Lentipes whittenorum } \\
\text { Lentipes ikeae }\end{array}$ & $\begin{array}{l}\text { Malaysia } \\
\text { Malaysia } \\
\text { India } \\
\text { Central Java } \\
\text { Central Java } \\
\text { Central Java } \\
\text { Bangladesh } \\
\text { Philippines } \\
\text { Philippines } \\
\text { Australia } \\
\text { West Java } \\
\text { Bali } \\
\text { West Java } \\
\text { Banten } \\
\text { Bali } \\
\text { East Java } \\
\text { Bali } \\
\text { West Java }\end{array}$ & $\begin{array}{l}\text { KX223903.1 } \\
\text { KX223902.1 } \\
\text { MG495939.1 } \\
\text { KU692539.1 } \\
\text { KU692538.1 } \\
\text { KU692535.1 } \\
\text { MK572237.1 } \\
\text { HQ682693.1 } \\
\text { HQ682695.1 } \\
\text { KJ669473.1 } \\
\text { KU693078.1 } \\
\text { KU693018.1 } \\
\text { KU693171.1 } \\
\text { KU693162.1 } \\
\text { KU693126.1 } \\
\text { KU693113.1 } \\
\text { KU693014.1 } \\
\text { KU692987.1 }\end{array}$ \\
\hline Cyprinidae & $\begin{array}{l}\text { Rasbora } \\
\text { Danio } \\
\end{array}$ & $\begin{array}{l}\text { Rasbora lateristriata } \\
\text { Danio rerio }\end{array}$ & India & $\begin{array}{l}\text { KT960818.1 } \\
\text { MK714084.1 } \\
\end{array}$ \\
\hline
\end{tabular}




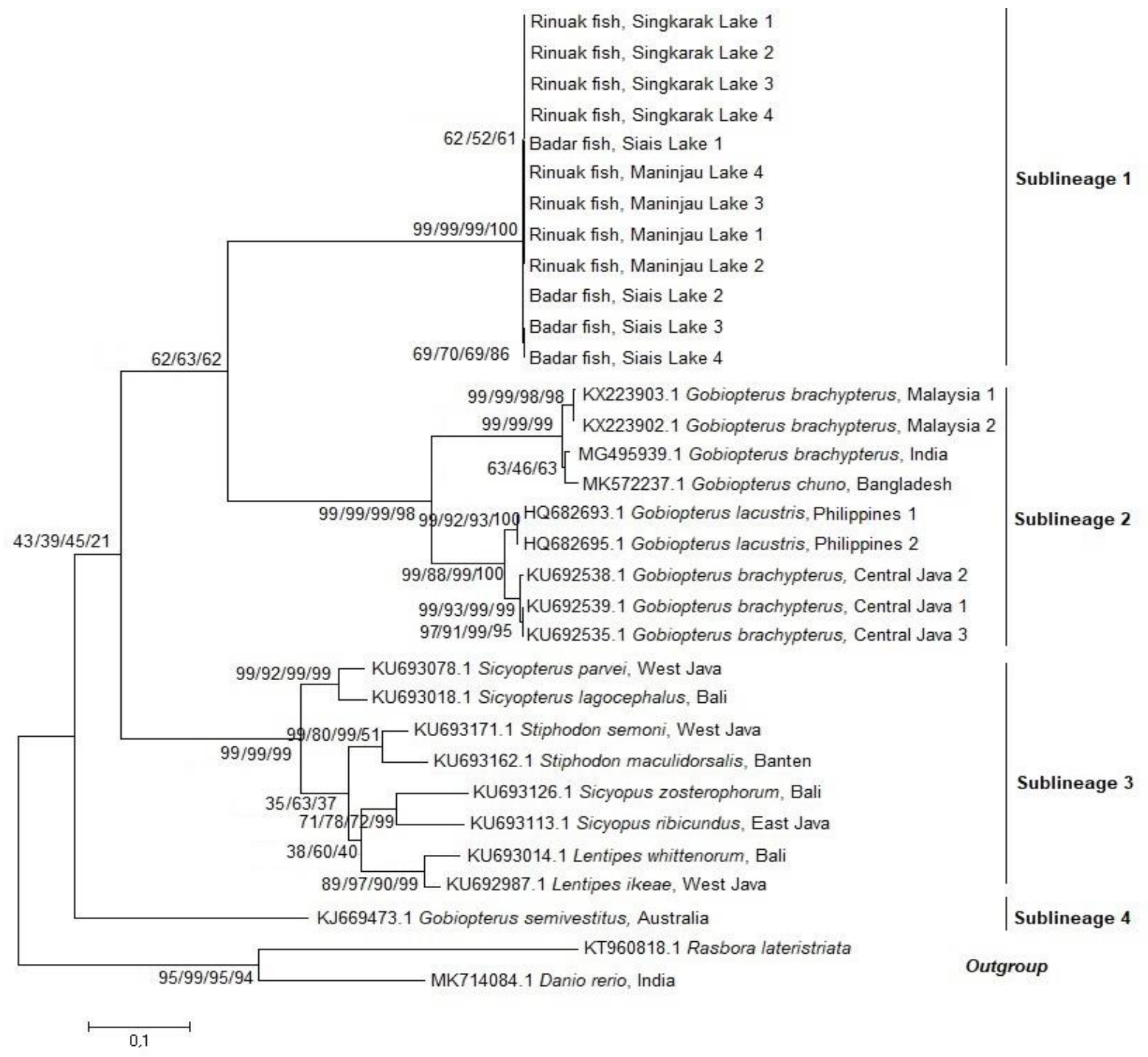

Figure 1. The ML phylogenetic tree of the COI gene with the bootstrap value of 1000 replicates (ME/NJ/ML/MP)

Morphological and genetic studies showed that environmental conditions play an essential role in determining the phenotype of a species. The phenotype shows the existence of high adaptability to environmental conditions without changing their genetic makeup. Akihito et al. (2000) reported that the adaptations of Gobiidae fishes to habitats had developed various morphological specializations. It is difficult to estimate the evolutionary scenario using only morphological information, so that needed the genetic data. The phylogenetic tree showed that the Gobiopterus is a sister taxon of Rinuak, and Badar fish with sequence divergences was 24.6-27.9\%. Based on Kartavtsev et al. (2011); Kartavtsev et al. (2013), these values show the different of the genus level. The same case also found in other studies of Gobiidae. Jeon et al. (2012) reported that the average sequence divergences of intragenus of more than 20 genera with multiple species of Gobies higher (21.09\%) than among species (9.93-9.54\%) in the study of Ward et al. (2005); Ward and Holmes (2007).
According to Kottelat (2013), the transparent gobies consist of two genera; Gobiopterus and Mistichthys. Mistichthys only has one species, Mistichthys luzonensis. Referring to Kottelat et al. (1993), Rinuak and Badar fish has similar in morphology with $G$. brachypterus. The similarity of the main characters between Rinuak and Badar fish with $G$. brachypterus consists of cheek naked, cheeks without raised ridges and flaps, pelvic thin without fleshy lobes, head pores absent, transparent body, cheek and margins of preopercle usually with a dark vertical mark, dorsal midline in front of the first dorsal usually with black pigments, mouth of males is more extensive than female and almost vertical and distance between eyeballs 0.5-1.0 times eyeball diameter. However, Rinuak and Badar fish have high sequence divergences (24.6-27.9\%) against $G$. brachypterus in Central Java, Malaysia, and India. Despite having the similarity in morphology, the high sequence divergences do not support the grouping of Rinuak and Badar fish as the same species to $G$. brachypterus even to the genus Gobiopterus. 
Previously, the transparent gobies were separated into several genera (Munro 1949) consists of Gobiopterus Bleeker (1874), Mistichthys Smith (1901), Micrapocryptes Hora (1923), Mirogobius Herre (1927), Gobiella Smith (1931), and Herreolus Smith (1931). However, previous authors (Hora 1934; Mukerji 1936; Aurich 1938; Koumans I940), demonstrated that Gobiopterus is a synonym of the re-examined holotype of Micrapocryptes, Gobiella, Mistichthys, and Mirogobius. While, Kottelat (2013) has reported that the valid of transparent gobies consists of two genera (Mistichthys and Gobiopterus), where is Gobiopterus has ten species. However, only four species of them have morphological and genetic data ( $G$. brachypterus, G. lacustris, G. chuno, and G. semivestitus). Unfortunately, there is no information explained in the published article about G. brachypterus in Rawa Pening lake, Central Java, which was used as a comparison species in the present analysis of the study.

According to (Kottelat 2013), the type locality of $G$. brachypterus (Bleeker 1955) in Pasuruan, Ranu Grati Lake, East Java, Indonesia. Based on the several sources, $G$. brachypterus in East Java are known with the local name as Lempuk fish. The local peoples consider Lempuk fish only found in Ranu Grati Lake (East Java). Lempuk fish also has high economic value as of fresh food and processed food like Rinuak fish from Maninjau Lake. The genetic similarity study of Lempuk fish and G. brachypterus using the 12s rRNA gene by Candra (2012) showed the high sequence divergences $(8.2 \%)$ between them and concluded that Lempuk fish was different genus to $G$. brachypterus. These results supported our study, which showed Rinuak and Badar fish as different from G. brachypterus. The lack of morphological and genetic studies on the Gobiopterus group makes it difficult for further identification. Studies on Gobiopterus are limited to the first records $G$. brachypterus in Sri Lanka (Ott 2011), sexual dimorphism of $G$. semivestitus (Macdowall and David 2008), and genetic differentiation of G. lacustris (Aquino et al. 2011; Wang et al. 2017).

The data of (IUCN 2010; IUCN 2019) and FishBase (2013) suggested that species of Gobiopterus are endemic to certain islands/countries; some are also found in other regions such as $G$. lacustris is endemic in the Philippines. However, Wang et al. (2017) reported that G. lacustris also found in China. Aquino et al. ( 2011) explained that $G$. lacustris divided into two distinct clusters with deep genetic divergence at $23.80 \%$ and proposed that they are a cryptic species. Wang et al. (2017) confirmed that no cryptic species on $G$. lacustris in the Philippines and supported that $G$. lacustris in China should not be an invasive species from the Philippines.

There are no photo vouchers, and the availability of the data of DNA sequences on GenBank and BOLD System to all Gobiopterus species causes the difficulties in identified and verified their taxonomy status. The taxonomy of Gobiidae has been studied extensively for the last decades, but confusion still exists (Jeon et al. 2012). The Present study revealed that Rinuak fish is not an endemic of Maninjau Lake. Rinuak and Badar exist as a different genus with Gobiopterus. Further comprehensive studies using the morphology and other molecular markers on Rinuak and Badar are ongoing.

\section{ACKNOWLEDGEMENTS}

We would like to thank to the Management of the Ministry of Research, Technology, and Higher Education whose support the funding of the research to Andalas University, Padang, Indonesia. Our thanks also expressed to Head of the Biology Department and the Dean of Faculty of Mathematics and Natural Sciences, Andalas University, Padang, Indonesia for field and Laboratory work permit. We also would like to thank our students who helped us in sample collection and laboratory works in Genetic and Biomolecular Laboratory, Faculty of Mathematics and Natural Sciences, Andalas University, Padang, Indonesia.

\section{REFERENCES}

Agorreta A, Ruber L. 2012. A Standardized Reanalysis of Molecular Phylogenetic Hypotheses of Gobioidei. Systematics And Biodiversity 10 (3): 375-390.

Agorreta A, San Mauro D, Schliewen U, Van Tassell JL, Kovacic M, Zardoya R, Ruber L. 2013. Molecular Phylogenetics of Gobioidei and phylogenetic placement of European Gobies. Mol Phylogenet Evol 69: 619-633.

Akihito A, Iwata T, Kobayashi T, Ikeo K, Imanishi T, Ono H, Umehara Y, Hamamatsu C, Sugiyama K, Ikeda Y, Sakamoto K, Fumihito A, Ohno S, Gojobori T. 2000. Evolutionary of gobioid fishes based upon a phylogenetic analysis of mitochondrial Cytochrome b Genes. Gene 259: 5-15.

Aquilino SVL, Tango JM, Fontanilla IKC, Pagulayan RC, Basiao ZU, Ong PS, Quilang JP. 2011. DNA Barcoding of the Ichthyofauna of Taal Lake, Philippines. Mol Ecol Resour 11: 612-619.

Aquino LMG, Tango JM, Canoy RJC, Fontanilla IKC, Basiao ZU, Ong PS, Quilang JP. 2011. DNA barcoding of fishes of Laguna de Bay, Philippines. Mitochondrial DNA 22 (4): 143-153.

Arisuryanti T, Hasan RL, Koentjana JP. 2018. Genetic identification of two mudskipper species (Pisces: Gobiidae) from Bogowonto Lagoon (Yogyakarta, Indonesia) using COI mitochondrial gene as a DNA barcoding marker. AIP Conf Proc 2002: 020068. DOI: 10.1063/1.5050164.

Astuti T, Yusra, Mardiah A. 2016. Quality study of processed rinuak fish (Psilopsis sp.) in Maninjau Lake, Tanjung Raya District, Agam Regency, West Sumatra. Katalisator 1 (1). DOI: 10.22216/jk.v1i1.982. [Indonesian]

Aurich HJ. 1938. Intern. Rev. Hydrobiol. xxxviii: 125-183.

Brown WM, George MJr, Wilson AC. 1979. Rapid evolution of animal mitochondrial DNA. Proc Natl Acad Sci USA 76: 1967-1971.

Burland TG. 2000. DNA STAR's Lasergene Sequence Analysis Software. Methods Mol Biol 132: 71-91.

Cailliet GM, Love MS, Ebeling AW. 1986. Fishes. A Field and Laboratory Manual on Their Structure, Identification and Natural History. 1st ed, Vol. 1. Waveland Press, Belmont, CA.

Chandra KF. 2012. Identification of Genetic Similarities between Gobiopterus Spp. in Ranu Grati Lake with Gobiopterus brachypterus based on 12s rRNA Gene. [Thesis]. Brawijaya University, Malang. [Indonesian].

FishBase. 2013. Gobiopterus lacustris. [Online]. www.fishbase.se/ summary/Gobiopterus-lacustris.html.

Froese R, Pauly D. 2004. Fishbase. A Global Information System on Fishes. [Online]. www.fishbase.org.

Hall TA. 1999. Bio Edit: A user-Friendly Biological Sequence Alignment Editor and Analysis Program for Windows 95/98/NT. Nucleic Acid Symposium Series 41: 95-98. 
Hebert PDN, Stoeckle MY, Zemlak TS, Francis CM. 2004. Identification of birds through DNA barcodes. PLoS Biol 2 (10): e312. DOI: 10.1371/journal.pbio.0020312.

Hora SL. 1934. Rees. Indian Mus. xxxvi: 483-490.

Hubert N, Hanner R, Holm E, Mandrak N, Taylor E. 2008. Identifying Canadian Freshwater Fishes through DNA Barcodes. PLoS One 3: e2490. DOI: 10.1371/journal.pone.0002490.

Imtiaz A, Mohd-Nor SA, Naim DM. 2017. Review: Progress and potential of DNA barcoding for indentification of fish species. Biodiversitas 18 (4): 1394-1405.

IUCN. 2010. Gobiopterus chuno. The IUCN Red List of Threatened Species 2010. [Online]. www.iucnredlist.org/species/168438/ 6492267.

IUCN. 2019. Gobiopterus birtwistlei. The IUCN Red List of Threatened Species 2019. [Online]. www.iucnredlist. org/ species/168438/6492267.

Jeon HB, Choi SH, Suk HY. 2012. Exploring the Utility of Partial Cytochrome C Oxidase Subunit-1 for DNA Barcoding of Gobies. Anim. Syst. Evol. Divers 28 (4): 269-278.

Jin XX, Wang R, Wei T, Tang D, Xu T. 2014. Complete Mitochondrial Genome Sequence of Tridentiger bifasciatus and Tridentiger barbatus (Perciformes, Gobiidae): A Mitogenomic Perspective on the Phylogenetic Relationships of Gobiidae. Mol Biol Rep. DOI: 10.1007/s11033-014-3768-3.

Johns GC, Avise JC, 1998. A Comparative Summary of Genetic Distances in the Vertebrates from the Mitochondrial Cytochrome b Gene. Mol Biol Evol 15: 1481-1490.

Kartavtsev YP. 2011. Divergence at Cyt-b and Co-I mtDNA Genes on Different Taxonomic Levels and Genetics of Speciation in Animals. Mitochondrial DNA 22: 55-65. DOI: $10.3109 / 1940$ 1736.2011.588215

Kartavtsev YP. 2013. Sequence Diversity at Cyt-b and Co-I mtDNA Genes in Animal Taxa Proved Neo-Darwinism. J. Phylogenet Evol Biol 1. DOI: 10.4172/2329-90 02.1000120.

Keith P, Galewski T, Cattaneo-Berrebi G, Hoareau T, Berrebi P. 2005 Ubiquity of Sicyopterus lagocephalus (Teleostei: Gobioidei) and phylogeography of the Genus Sicyopterus in the Indo-Pacific Area Inferred from mitochondrial Cytochrome b Gene. Mol Phylogenet Evol 37: 721-732.

Kottelat M, Whitten AJ, Kartikasari SN, Wiejoatmodjo S. 1993 Freshwater Fishes of Western Indonesia and Sulawesi. Periplus Editions. (HK) Ltd., Singapore, and EMDI, Jakarta, Indonesia

Kottelat M. 2013. The fishes of the inland waters of Southeast Asia: A catalogue and core bibliography of the fishes known to occur in freshwaters, mangroves and estuaries. Raffles Bull Zool. Suppl 27: 1 663.

Koumans FP. 1931. A preliminary revision of the genera of the gobioid fishes with united ventral fins. Proefschrift Drukkerij Imperator N.V. Lisse, 1-174.

McDowall RM, David BO. 2008. Gobiopterus in New Zealand (Teleostei: Gobiidae), with Observations on Sexual Dimorphism, New Zealand. J Mar Freshw Res 42 (3): 325-331. DOI: 10.1080/002883308 09509960.

McGlashan DJ, Hughes JM. 2001. Low levels of Genetic Differentiation Among Populations of the Freshwater Fish Hypseleotris compressa (Gobiidae: Eleotridinae): Implications for its Biology, Population Connectivity and History. Heredity $86: 222-233$.

Mukerji DD. 1936. Recs. Indian Mus. xxxviii: 9-13.

Munro ISR. 1949. A New Genus and Species of Transparent Gobioid Fish from Australia. Ann Mag Nat Hist Ser 12, 2 (15): 229-240. DOI: 10.1080/00222934908653984.

Nelson JS. 2006. Fishes of the World. 4th ed. John Wiley and Sons Inc, New York.

Olii AH, Sahami FM, Hamzah SN, Pasisingi N. 2019. Molecular approach to identify gobioid fishes, "nike" and "hundala" (local name), from
Gorontalo Waters, Indonesia. Online J Biol Sci (1): 51-56. DOI: 10.3844/Ojbsci.201951.56.

Ott G. 2011. First Records of Gobiopterus brachypterus and Mugilogobiustigrinus from Sri Lanka (Teleostei, Perciformes, Gobiidae: Gobionellinae). Bull Fish Biol 13 (1/2): 71-75.

Periwaldi RAP. 2012. Studi Morfologi Ikan Badar Danau Siais Sumatera Utara Dan Ikan Rinuak Danau Maninjau Sumatera Barat. (Morphological Study of Badar Fish in Siais Lake, North Sumatra and Rinuak Fish in Maninjau Lake, West Sumatra). [Thesis]. Andalas University, Padang. [Indonesian].

Pezold F. 1993. Evidence for a Monophyletic Gobiinae. Copeia : 634-643.

Pfeil VDF. 2009. The Fishes of the Batang Hari drainage, Sumatra, with Description of Six New Species. Ichthyol. Explor Freshw 20 (1): 1369.

Roesma DI, Tjong DH, Karlina W, Aidil DR. 2019. Taxonomy Confirmation of Puntius cf. binotatus from Gunung Tujuh Lake, Jambi, Indonesia based on Cytochrome Oxidase-I (COI) Gene. Biodiversitas 20 (1): 54-60

Roesma DI, Tjong DH, Munir W, Aidil DR. 2018. New Record Species of Puntius (Pisces: Cyprinidae) from West Sumatra based on Cytochrome Oxidase I Gene. Intl J Adv Sci Eng Inform Technol 8 (1): 250-256.

Roesma DI., Santoso P. 2010. Fishes in Lake Siais and adjoining rivers of the Angkola-Siondop wilderness forest ecosystem, North Sumatra, Sumatra, Indonesia. In: Yanuar A. (ed.). A Biological Assessment of the Angkola-Siondop Wilderness Forest Ecosystem, Northwestern Sumatra, Indonesia. Conservation International-Indonesia, Jakarta.

Rozas J, Sanchez-DelBarrio JC, Messeguer X, Rozas R. 2003. DnaSP, DNA polymorphism analyses by the coalescent and other methods. Bioinformatics 19: 2496-2497. DOI: 10. 1093/ bioinformatics/btg359.

Sodhi NS, Brook BW. 2006. Southeast Asian Biodiversity in Crisis. Cambridge University Press, Cambridge.

Taillebois L, Castelin M, Lord C, Chabarria R, DettaI A, Keith P. 2014 New Sicydiinae phylogeny (Teleostei: Gobioidei) inferred from mitochondrial and nuclear genes: insights on systematics and ancestral areas. Mol Phylogenet Evol 70: 260-271.

Tamura K, Stecher G, Peterson D, Filipski A, Kumar S. 2013. MEGA 6: Molecular Evolutionary Genetics Analysis Version 6.0. Mol Biol Evol 30: 2725-2729.

Thacker CE. 2009. Phylogeny of Gobioidei and Placement within Acanthomorpha, with a new classification and investigation of diversification and character evolution. Copeia 1: 93-104.

Thacker CE. 2015. Biogeography of goby lineages (Gobiiformes: Gobioidei): origin, invasions and extinction throughout the Cenozoic. J Biogeogr 42: 1615-1625.

Thompson JD, Gibson TJ, Plewniak F, Jeanmougin F, Higgins DG. 1997. The Clustal X Windows Interface: Flexible strategies for multiple sequence alignment aided by quality analysis tools. Nucleid Acids Res 24: 4876-4882.

Tornabene L, Ahmadia G, Berumen M, Smith D, Jompa J, Pezold F. 2013. Evolution of microhabitat association and morphology in a diverse group of Cryptobenthic Coral Reef Fishes (Teleostei: Gobiidae: Eviota). Mol Phyl Evol 66: 391-400.

Wang ZD, Liao J, Huang CQ, Long SS, Zhang S, Guo YS, Liu L, Liu CW. 2017. Significant genetic differentiation of Gobiopterus lacustris, a newly recorded transparent goby in China. Mitochondrial DNA Part A. DOI: 10.1080/24701394.2017.1357712.

Ward RD, Holmes BH. 2007. An analysis of nucleotide and amino acid variability in the barcode region of Cytochrome C Oxidase I (CO1) in fishes. Mol Ecol Notes 7: 899-907.

Ward RD, Zemlak TS, Innes BH, Last PR, Hebert PDN. 2005. DNA Barcoding Australia's fish species. Philos Trans R Soc B 360: 1847 1857. 